\title{
PRODUCTION AND CHARACTERIZATION OF HYDROXYAPATITE BONE SUBSTITUTE MATERIAL PERFORMED FROM INDONESIAN LIMESTONE
}

\author{
Sudirman Habibie ${ }^{1, a}$, Agus Hadi Santosa Wargadipura ${ }^{1}$, Dwi Gustiono ${ }^{1}$, \\ Nendar Herdianto ${ }^{1}$, Asep Riswoko ${ }^{1}$, Siti Nikmatin ${ }^{2}$, Stephen Clarke ${ }^{3}$ \\ ${ }^{1}$ Center for Material Technology, Agency for the Assessment and Application of \\ Technology, 224 ${ }^{\text {th }}$ Building, Puspiptek Area, Serpong, South Tangerang - Banten 15314, \\ Indonesia \\ ${ }^{2}$ Physics Department, Bogor Agricultural University, Indonesia \\ ${ }^{3}$ Advanced Material Solutions, Australia
}

\begin{abstract}
Limestone which is one of the raw materials for the manufacture of materials and medical devices obtained scattered in almost all provinces in Indonesia. In this paper, the making hydroxyapatite using limestone as the raw material was studied. Synthesis of hydroxyapatite was done using precipitation method. The main material of forming a hydroxyapatite in this study is diammonium hydrogen phosphate and calcination of limestone at $900^{\circ} \mathrm{C}$ for 4 hours that produce calcium oxide (CaO). The pure calcium oxide was observed in order to know the effect of calcium solution addition rate and calcium precursor size. The calcium oxide precursor was prepared with high energy milling (HEM). HEM usage is intended to produce a precursor size of calcium in nano size. Furthermore, the characterization of second phase precursors using x-ray diffraction (XRD), analysis of morphology and element content using scanning electron microscopy-energy dispersive X-ray (SEM-EDX) and analyzes the size and distribution of particles of calcium resulted from milling using a particle size analyzer ( PSA).
\end{abstract}

\section{KEYWORDS:}

Limestone, hydroxyapatite, precipitation method, x-ray diffraction, SEM-EDX, particle size analyzer.

\section{INTRODUCTION}

Limestone constitutes as one of non-metallic minerals industry that is enormous potential and spread almost throughout the territory of Indonesia ${ }^{1)}$. Potential limestone Indonesia is very large and spread its presence in almost every province as shown in table 1. Limestone reserves are already known is about 28.7 billion, and the biggest is in West Sumatra province, namely 23.23 billion tons, or about $81.02 \%$ of the full backup.

Limestone can occur in several ways that is organic, mechanical or chemical ways, example of limestone see Figure 1. Most of limestone that are occurring organic in nature, this type comes from precipitation shell/shells and snails, foraminifera or algae, or is derived from animal skeletons of corals/clams. Limestone can be creamy white, light gray, gray host, brown and even black, depending on the presence of mineral impurities. ${ }^{2)}$

DOI: 10.5121/ijbes.2017.4102 
According to some previous studies, the average levels of limestone found in Indonesia contain between $40-45 \% \mathrm{CaO}$ see Table 2 . This is a great potential in its utilization as an industrial raw material. As seen in Table 2 that most of the components contained by limestone in Indonesia is calcium oxide $(\mathrm{CaO})$, which is the main component for cement raw material and ceramic hydroxyapatite, while the other components are relatively smaller. This is the reason for researchers to make limestone in Indonesia as a source of raw material for making hydroxyapatite ceramic bone substitute.

Carbonate minerals commonly found associated with limestone is aragonite, which would then be transformed into calcite $\left(\mathrm{CaCO}_{3}\right)$. Other minerals associated with limestone, but in small quantities are siderite, ankerit and magnesite $\left(\mathrm{MgCO}_{3}\right){ }^{2}{ }^{2}$ Donald D. Carr and Rooney L.F in $1985^{3)}$ makes the classification on the basis of the content of the mineral calcite and dolomite as well as non-carbonate material in rocks. If the content of calcite in rocks dominant, it can be said as a rock limestone. If the content of dolomite $\left(\mathrm{MgCO}_{3}\right)$ the most $(>15 \%)$ the rocks are classified as dolomite rocks.

Bones and teeth are an important part of the human body. Damage to bone tissue and tooth structure can cause disability and cause malfunctioning of the body. Efforts to improve the structure of bone tissue and teeth can be done with the addition and replacement of tissues. ${ }^{4)}$ The addition and replacement of tissues or commonly known as bone implants and dental aims to improve the state of form and function is normal, comfort, and overall good health. ${ }^{4)}$

Table 1. Limestone reserves of Indonesia by Province

\begin{tabular}{|c|c|c|c|}
\hline No. & Province & $\begin{array}{c}\text { Amount } \\
\text { (million tonnes) }\end{array}$ & Information \\
\hline 1 & DI Aceh & 100,857 & \multirow{17}{*}{$\begin{array}{l}\text { Entire limestone } \\
\text { reserves is } \\
\text { classified as } \\
\text { inferred mineral } \\
\text { resources } \\
\text { (including } \\
\text { hypothetical and } \\
\text { speculative), } \\
\text { except reserves } \\
\text { in East Nusa } \\
\text { Tenggara, a } \\
\text { number of } \\
\text { 61.376 million } \\
\text { tonnes as } \\
\text { reserves } \\
\text { (probable) } \\
\text { indicated }\end{array}$} \\
\hline 2 & North Sumatera & 5,709 & \\
\hline 3 & West Sumatera & $23,273,300$ & \\
\hline 4 & Riau & 6,875 & \\
\hline 5 & South Sumatera & 48,631 & \\
\hline 6 & Bengkulu & 2,730 & \\
\hline 7 & Lampung & 2,961 & \\
\hline 8 & West Java & 672,820 & \\
\hline 9 & $\begin{array}{l}\text { Central Java \& DI } \\
\text { Yogyakarta }\end{array}$ & 125,000 & \\
\hline 10 & East Java & 416,400 & \\
\hline 11 & South Kalimantan & $1,006,800$ & \\
\hline 12 & Central Kalimantan & 543,000 & \\
\hline 13 & West Nusa Tenggara & $1,917,386$ & \\
\hline 14 & East Nusa tenggara & 229,784 & \\
\hline 15 & North Sulawesi \& Gorontalo & 66,300 & \\
\hline 16 & South Sulawesi & 19,946 & \\
\hline 17 & Papua & 240,000 & \\
\hline
\end{tabular}

Source: Industrial Minerals, Limestone, Haryadi Treasure et al. 1997 


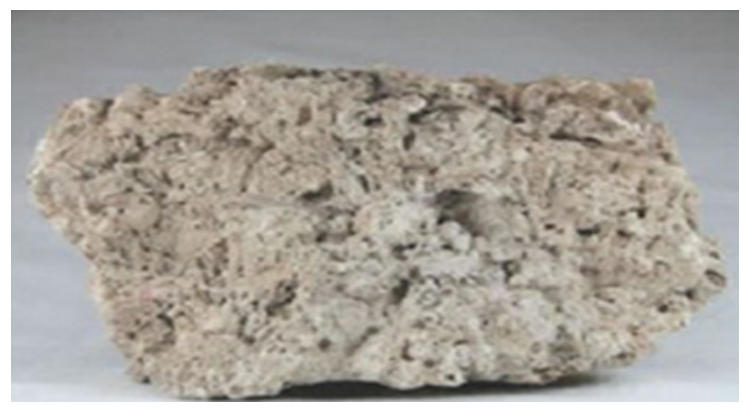

Figure 1. Example of limestone

Table 2. Levels of Limestone Indonesia ${ }^{23}$

\begin{tabular}{|c|c|c|}
\hline 1 & $\mathrm{CaO}$ & $40-45 \%$ \\
\hline 2 & $\mathrm{SiO}$ & $0.23-18,12 \%$ \\
\hline 3 & $\mathrm{Al}_{2} \mathrm{O}_{3}$ & $0.20-4.33 \%$ \\
\hline 4 & $\mathrm{Fe}_{2} \mathrm{O}_{3}$ & $0.10-1.36 \%$ \\
\hline 5 & $\mathrm{MgO}$ & $0.05-4.26 \%$ \\
\hline 6 & $\mathrm{CO}_{2}$ & $35.74-42.78 \%$ \\
\hline 7 & $\mathrm{H}_{2} \mathrm{O}$ & $0.10-0.85 \%$ \\
\hline 8 & $\mathrm{P}_{2} \mathrm{O}_{3}$ & $0.072-0.109 \%$ \\
\hline 9 & $\mathrm{~K}_{2}$ & $0.18 \%$ \\
\hline 10 & $\mathrm{LOI}$ & $40.06 \%$ \\
\hline
\end{tabular}

So far, the limestone is widely used for building materials such as poles for plaster, masonry mortar, cement manufacturing tras or red cement. Limestone also serves to reduce the plasticity, reduce shrinkage and expansion of the foundation of the highway. Uniquely, limestone can also be used as pest control, ie as lead and arsenic as arsenic calcium (CaAsO) or as sulfur powders to be sprayed. Not only that, the world of agriculture, public sprinkled powdered limestone to neutralize the acidic soil that is relatively not much water, as a fertilizer to increase the element calcium is reduced due to the harvest, as well as for loosening soil erosion. Limestone is also used as a disinfectant in poultry, in composting and so on. The other is the use of limestone as a water purifier. In a softening purification of water for industry, lime is used together with soda ash in a process called the soda lime process. One of the main functions of the limestone is in the cement industry and is the main raw material of cement.

The main inorganic minerals found in bone and teeth have a crystal structure consisting of calcium and phosphate. Calcium and phosphate in bone forming compound apatit. ${ }^{5)}$ Hydroxyapatite $\left[\mathrm{Ca}_{10}\left(\mathrm{PO}_{4}\right)_{6}(\mathrm{OH})_{2}, \mathrm{HAp}\right]$ is one of the apatite powder contained in the bones and teeth $^{6,7)}$. Raw materials that can be used to make hydroxyapatite widely found in nature, such as limestone, egg shells, rocks and shells. The calcium present in bone-shaped compound that binds to a phosphate group, hydroxides and carbonates. ${ }^{8)}$ Hydroxyapatite is a bioactive that can bring a specific response resulting interfacial bonding material between the network and the material, so that HAp can form a bond with the bone and stimulate the growth of new bone., ${ }^{910)}$ Bioactive is a medical condition that must be met in order HAp can be implanted in the human body. Other requirements that have to be compatible and non-toxic. ${ }^{11)}$ Calcium sulfate (limestone/gypsum) is a substance that was first used as a substitute for bone (bone substitutes). This substance has a very quick turnover and nearly all reabsorbed within a few weeks after implantation. ${ }^{12,13)}$ 
Human bones generally consists of two main components, namely two-thirds and one-third of non-organic phases organic phase. Most of the organic phase composed of nano-meter-sized collagen. And other constituents: proteins, fats and polysaccharides that provide the nature of flexible, elastic and strong. ${ }^{14)}$ Hydroxyapatite $\left[\mathrm{Ca}_{10}\left(\mathrm{PO}_{4}\right)_{6}(\mathrm{OH})_{2}\right]$, which is usually abbreviated HAp is a component that forms the majority of human bones and teeth ${ }^{15)}$. Hydroxyapatite has been widely used for biomedical implants, hard tissue surgery, bone regeneration, repair, filling, expand and reconstruct the damaged bone tissue ${ }^{16)}$.

The bone damage can be caused by traffic accidents, work accidents and osteoporosis. In addition, natural disasters such as the falling debris of the building when an earthquake can also be the cause of the increase in patients requiring bone implants. ${ }^{17)}$ Bone is living tissue that serves as a frame, a patron and protector of organs as well as a liaison between the muscles that allow movement ${ }^{18)}$. Damaging to the bone results in disruption of the function so that the bone needs to be repaired. One alternative that has been developed in the use of bone implant is a biomaterials ${ }^{19)}$.

Hydroxyapatite $\left[\mathrm{Ca}_{5}\left(\mathrm{PO}_{4}\right)_{3}(\mathrm{OH})\right]$ is a calcium apatite crystals are widely used as a bone implant because of its ability to synergize with the human body. Aside from being a bone implant, hydroxyapatite crystals also serves as an absorber of heavy metals, radioactive waste stabilizer and is under study for use as catalysts. Commercial Hydroxyapatite is made with several techniques, such as by wet chemical method (precipitation), hydrothermal technique, hydrolysis of calcium phosphate, or sol-gel reaction of which were classified as high-cost production. The high cost of production makes many researchers are trying to find alternative manufacturing of hydroxyapatite from natural sources that are cheaper.

This research aims to study the manufacturing process of the hydroxyapatite from limestone, studying the effect of operating conditions of time and temperature of combustion, as well as the analysis of X-Ray Difractometer the more dominant operating conditions give different looks physically to determine the effect of the crystallinity of the sample.

\section{MATERIALS AND METHODS}

\subsection{Materials}

In this experiment used limestone from karsts Mountain Bogor areas as a source of calcium and diamonnium phosphate $\left[\left(\mathrm{NH}_{4}\right)_{2} \mathrm{HPO}_{4}, 99.99 \% \mathrm{w}\right.$, Merck] as a source of phosphate and ammonia $\left(\mathrm{NH}_{4} \mathrm{OH}, 42 \% \mathrm{w}\right.$, Merck), distilled water, paper strain, and $96 \%$ ethanol. Calcium precursor prepared by washing, drying and crushing limestone to remove impurities and homogenize the size of limestone. Then calcium oxide $(\mathrm{CaO})$ synthesized by limestone powder calcination at $900^{\circ} \mathrm{C}$ for 4 hours, after it was destroyed by the motor grinder called samples $\mathrm{C} 0$, on the other hand the other samples were destroyed by HEM (high-energy milling PW 700i mixer / Mill) at speed $1000 \mathrm{rpm}$ varies with the duration of milling, whereas C1, C2, C3 samples at 90, 180, 270 minutes respectively.

\subsection{Methods}

Hydroxyapatite nanoparticles prepared by wet chemical methods of preparation $1 \mathrm{M}$ solution of calcium oxide $(\mathrm{CaO}$ coming from limestone without grinding and HEM preparation) and $0.6 \mathrm{gr} / \mathrm{lt}$ $\left[\left(\mathrm{NH}_{4}\right)_{2} \mathrm{HPO}_{4}\right]$ is used as the initial solution. The solution of $\left(\mathrm{NH}_{4}\right)_{2} \mathrm{HPO}_{4}$ added dropwise in a solution of calcium oxide. The level of addition of $\left(\mathrm{NH}_{4}\right)_{2} \mathrm{HPO}_{4}$ varies for calcium precursors 
without milling $(\mathrm{C} 0)$ to investigate the effect of variations in the level of addition of $\left(\mathrm{NH}_{4}\right)_{2} \mathrm{HPO}_{4}$ of the morphology of HAp. The variation of titration level of $\left(\mathrm{NH}_{4}\right)_{2} \mathrm{HPO}_{4}$ is 2,4 , and 12.5 $\mathrm{ml} / \mathrm{min}$ for sample $\mathrm{HA} 1 \mathrm{C} 0, \mathrm{HA} 2 \mathrm{C} 0$ and $\mathrm{HA} 3 \mathrm{C} 0$ respectively. On the other hand, the addition of $\left(\mathrm{NH}_{4}\right)_{2} \mathrm{HPO}_{4}$ for calcium precursors with $\mathrm{HEM}(\mathrm{C} 1, \mathrm{C} 2, \mathrm{C} 3)$ were set at $2 \mathrm{ml} / \mathrm{min}$ labelled as a sample HA1C1, HA1C2, HA1C3, by the influence of the size of the precursor at Hap morphology can be investigated. Ammonia was used for adjustment of $\mathrm{pH}$ values. The suspension is stirred with a magnetic stirrer after the addition of the initial solution for 24 hours at room temperature. Precursor done for 30 minutes at room temperature, then filtered and washed with a vacuum Buchner for five times until a neutral $\mathrm{pH}$ is reached. For the first and third phases were washed with distilled water and ammonia, the second phase and the fourth was washed with distilled water to remove residual dirt, and last washed with ethanol to remove water and increase the dispersibillity. The end product was dried at room temperature for 24 hours then heated to $160^{\circ} \mathrm{C}$ for 17 hours for the removal of water. Sintering process was carried out at $650^{\circ} \mathrm{C}$ with a heating rate of 80 minutes with a time of 2 hours detention. Experimental procedure for the synthesis of HA powder is shown in Figure 2.

Calcium oxide powder was characterized by X-ray Diffractometer (Phillips, Shimadzu 610) and hydroxyapatite samples characterized by XRD and hydroxyapatite nanocrystalline morphology characterized by scanning electron microscopy (SEM) and transmission electron microscopy (TEM).

\section{RESULT AND DISCUSSION}

Hydroxyapatite synthesis process involves by reacting a precursor of calcium from limestone with diammonium hydrogen phosphate $\left[\left(\mathrm{NH}_{4}\right)_{2} \mathrm{HPO}_{4}, \mathrm{DAP}\right]$ using precipitation method. This method is one of bottom-up technical approaches. By combining the two methods in nanotechnology is expected to produce nanocrystalline hydroxyapatite. The result achieved is a hydroxyapatite phase characterization, crystal size and lattice parameter with XRD, morphological analysis and content element by SEM-EDX, and Siza crystal structure analysis by transmission electron microscopy (TEM)

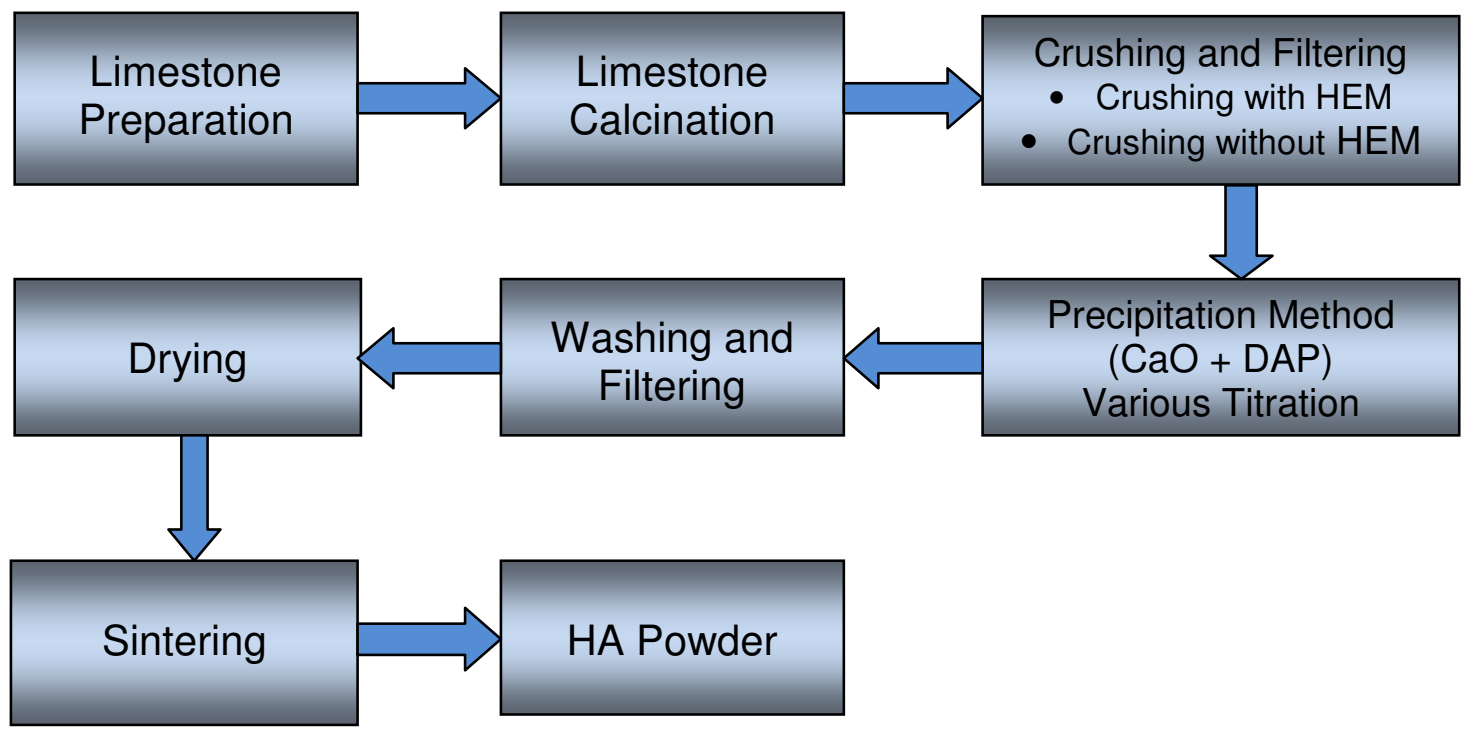

Figure 2. A flow sheet of synthesis of HA powders by precipitation method 
International Journal of Biomedical Engineering and Science (IJBES), Vol. 4, No. 1, January 2017

\section{CHARACTERIZATION OF CALCIUM PRECURSOR OF LIMESTONE}

XRD characterization was conducted to determine the phase contained in limestone. Qualitative analysis using XRD of limestone powder used software Match !. From the matching results it is known that the limestone samples is dominated by the phase $\mathrm{Ca}\left(\mathrm{CO}_{3}\right)$ and $\mathrm{Ca}(\mathrm{OH})_{2}$ with reference to the standard diffraction ICDD No.84-1263 to $\mathrm{Ca}(\mathrm{CO})_{3}$ and ICDD No.47-1743 to $\mathrm{Ca}(\mathrm{OH})_{2}$. Phase formed on the X-ray diffraction pattern before the limestone calcination process is shown in Figure 3. Limestone composed of calcium carbonate $\left(\mathrm{CaCO}_{3}\right)$ is used as the starting material for manufacturing of calcium oxide $(\mathrm{CaO}){ }^{8,9)}$

The independent variables used in the manufacture of calcium precursor is the process of miling and without miling process. Calcium precursor manufacture begins with calcination of limestone. In theory, the calcination temperature and time will affect the quality of the resulting calcium oxide. Sukandarrumi in Amri et al. stated that the limestone calcination temperature is $900^{\circ} \mathrm{C} .^{20}$ ) So in this study the calcination of limestone carried out at a temperature of $900^{\circ} \mathrm{C}$ for 4 hours. Samples obtained were homogenized to achieve a uniform size of $45 \mathrm{~lm}$. Reaction formation of $\mathrm{CaO}$ through a calcination process can be seen in equation (3) below.

The independent variables used in the manufacture of calcium precursor is milling and without milling process. Calcium precursor manufacture begins with calcination of limestone. Based on the theory of calcination, temperature and time will affect the quality of the resulting calcium oxide. Sukandarrumi in Amri et al. states that the calcium limestone calcination temperature is $900^{\circ} \mathrm{C} .{ }^{20)}$ So in this study, the calcination of limestone carried out at a temperature of $900^{\circ} \mathrm{C}$ for 4 hours. Samples obtained homogenized to achieve a uniform size of $45 \mu \mathrm{m}$. Reaction formation of $\mathrm{CaO}$ through a calcination process can be seen in equation (1) below.

$$
\mathrm{CaCO}_{3} \rightarrow \mathrm{CaO}+\mathrm{CO}_{2}
$$

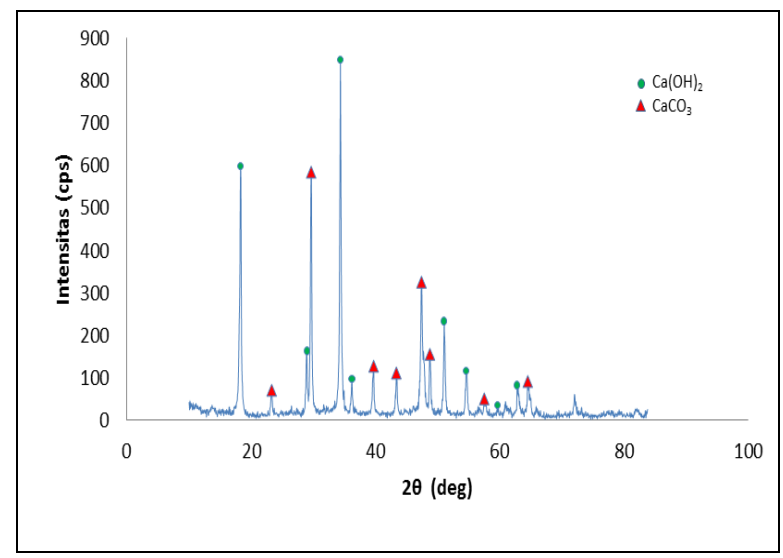

Figure 3. Diffractogram limestone before calcination 
In the calcination process, weight of limestone would decrease. The efficiency of calcination process determined by mass difference before and after calcination process of limestone. Results and efficiency of calcination can be seen in Table 3.

Table 3. Mass of the calcination result of limestone $\left(900^{\circ} \mathrm{C}, 4\right.$ hours) and its efficiency

\begin{tabular}{|c|c|c|c|}
\hline \multirow[b]{2}{*}{ Repeat } & \multicolumn{2}{|c|}{ The weight of limestone } & \multirow[b]{2}{*}{$\begin{array}{c}\text { Efisiens } \\
(\%)\end{array}$} \\
\hline & $\begin{array}{l}\text { Before calcination } \\
\text { (gram) }\end{array}$ & $\begin{array}{l}\text { After calcination } \\
\text { (gram) }\end{array}$ & \\
\hline 1 & 157.00 & 112.43 & 71.61 \\
\hline 2 & 171.79 & 134.95 & 78.55 \\
\hline \multicolumn{3}{|c|}{ Average } & 75.08 \\
\hline
\end{tabular}

Calcium oxide $(\mathrm{CaO})$ resulted from the calcination process is $\mathrm{C} 0$ sample, which is a precursor of calcium without milling. To further examine, the sample $\mathrm{CO}$ were characterized using XRD. XRD characterization of samples $\mathrm{C} 0$ to produce a diffraction pattern with highest intensity at an angle $2 \theta \quad 32.25^{\circ} ; 37.41^{\circ} ; 53.91^{\circ} ; 64.22^{\circ}$ and $67.44^{\circ}$. This Value $2 \theta$ is specific to the compound $\mathrm{CaO}$ accordance with standard diffraction pattern of JCPDS and ICDD No.77-2376 which indicates the presence of phase $\mathrm{CaO}$ in the sample phase limestone of calcination results. The XRD pattern after calcination of limestone samples shown in Figure 4.

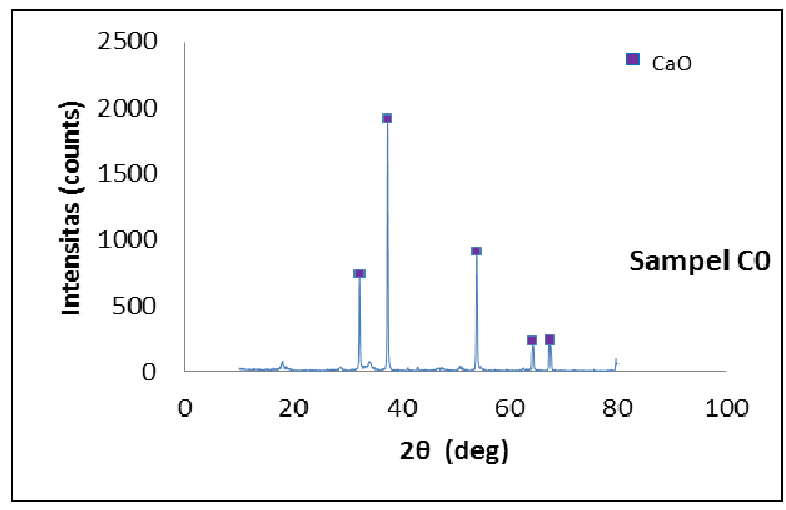

Figure 4. Diffractograms after calcination of limestone (sample C0)

To determine the morphology and element content of the samples C0 was carried out SEM-EDX analysis. Microscopic morphology of $\mathrm{C} 0$ sample is shown in Figure 5. From the SEM photograph that the morphology $\mathrm{CaO}$ looked like dots of interlocking with one another and formed agglomeration (clot). In figure 5(c) demonstrated two dominant elements contained in the sample $\mathrm{CO}$ is the element $\mathrm{Ca}$ and $\mathrm{O}$. This strengthens the XRD analysis results stating that the samples $\mathrm{C} 0$ contains $\mathrm{CaO}$ phase. In addition there are also other elements such as $\mathrm{C}, \mathrm{Mg}, \mathrm{Al}$ and $\mathrm{Si}$ are so few that are considered as impurities that can be ignored. 


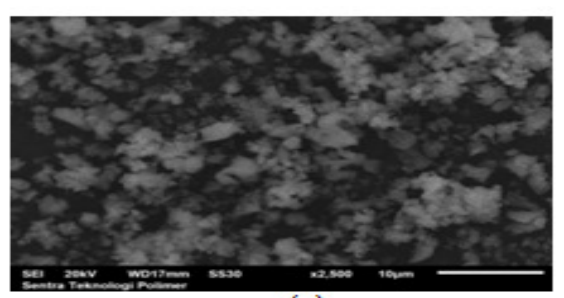

(a)

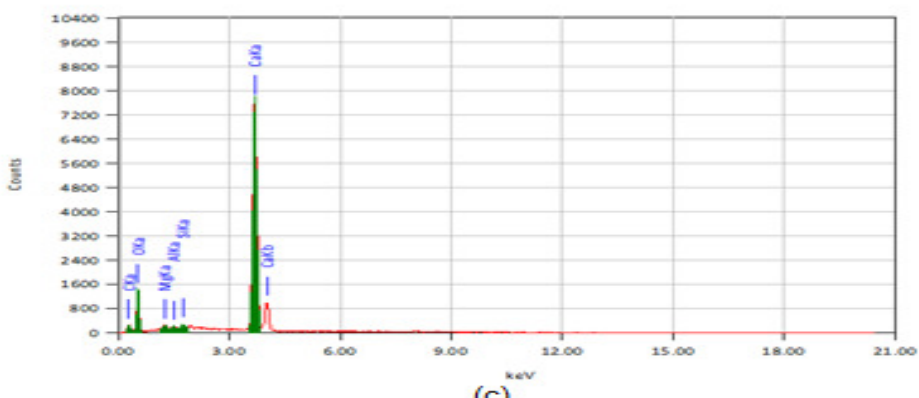

(c)

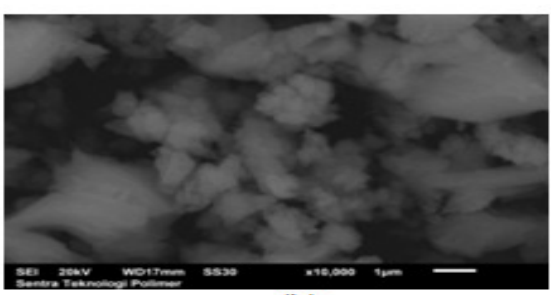

(b)

Figure 5. SEM micrographs of calcium oxide (Sample C0) (a) magnification 2.500x (b) magnification 10.000x and (c) the data EDX

Variations of second calcium precursor was produced from milling of the compound calcium oxide $(\mathrm{CaO})$ using a high energy milling (HEM) by varying the length of milling time. After that, the samples were heated at $400^{\circ} \mathrm{C}$ for 2.5 hours. Heating aims to remove impurities in the sample. XRD characterization was conducted to determine the phase contained in the sample resulted from milling process. The results showed that all three samples $(\mathrm{C} 1, \mathrm{C} 2$ and $\mathrm{C} 3)$ is dominated by the phase $\mathrm{Ca}(\mathrm{OH})_{2}$ and $\mathrm{CaO}$. This refers to the standard diffraction ICDD No. 84-1263 for $\mathrm{Ca}(\mathrm{OH})_{2}$ and ICDD No. 37-1497 for $\mathrm{CaO}$. Milling process results in changing a $\mathrm{CaO}$ phase into $\mathrm{Ca}(\mathrm{OH})_{2}$. The $\mathrm{CaO}$ phase has not changed completely into phase $\mathrm{Ca}(\mathrm{OH})_{2}$ but the longer time of milling process, the $\mathrm{Ca}(\mathrm{OH})_{2}$ phase are also increasingly dominant as shown in Figure 6.

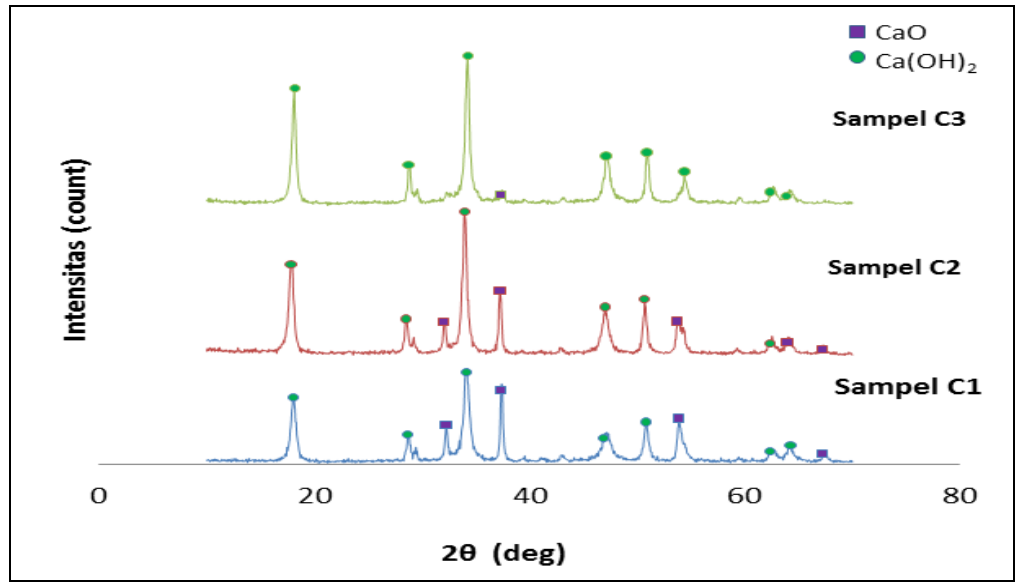

Figure 6. Diffractograms after milling limestone (sample C1, C2 and C3) 
During milling process, the mechanical grinding occurs resulting particle size becomes smaller. Particle size analysis was done by using a PSA. The PSA measurement principle is dynamic light scattering (DLS). In the measurement, sample is dissolved using distilled water. Materials in the nanometer or submicron size usually have a tendency to agglomerate (clot). Sample measurements with this method is considered quite good because the particles are dispersed into the media so that the particles did not agglomerate. Therefore, the measured size is the size of a single particle.

DLS treat the scattering particles (particles of calcium) in the solution is more realistic. Particles that every time undergoing a process of diffusion treated as particles that moves dynamically with Brownian motion. The concentration of particles in a given volume element will always fluctuate and particle concentration fluctuations associated with the motion of the particle diffusion. ${ }^{21)}$

Diffusion causes the position and orientation of scattering particles is always changing with time. It causes the phase and polarization of light scattered by each particle changes with time. So that, the intensity of scattered light with a certain polarization will also fluctuate over time. Self correlation function of the electric field of the first order fluctuation of the scattered light intensity is given by equation (2). ${ }^{21}$

$$
g^{(1)}(k, \tau)=\exp (-\Gamma \tau)
$$

with a decay constant $\Gamma$ and $\tau$ is a time delay. The decay constant $\Gamma$ is obtained by matching the data with the least square curve. Mathematically the relationship between $\Gamma$ with translational diffusion coefficient $\mathrm{D}$ is given by

$$
\Gamma=D k^{2}
$$

$\mathrm{k}$ is scattering vector given by

$$
k=\frac{4 \pi n_{2} \sin \left(\frac{\theta}{2}\right)}{\lambda_{o}}
$$

$\mathrm{n}_{2}$ the refractive index of the solvent, the scattering angle $\theta$ and the wavelength of light $\lambda_{o}$ in a vacuum. The value translational diffusion coefficient is

$$
a=\frac{k_{E} T}{3 \pi \eta D}
$$

With

$$
\begin{aligned}
k_{\Xi} & =\text { Boltzmann constant }\left(1.3807 \times 10^{-23} \mathrm{~J} . \mathrm{K}^{-1}\right) \\
T & =\text { absolute temperature } \\
\eta & =\text { viscosity solvent } \\
d & =\text { particle diameter }
\end{aligned}
$$

Magnitudes, $k_{E}, \eta, \mathrm{T}, \mathrm{n}_{2}, \lambda$, and $\Theta$, their value are limited because they are a constant. By entering the value of the constants in the equation (5), we know the value of the particle diameter. The calculation process is not done manually but using computer software. 
The measurement results in the form of distribution that can be assumed to describe the overall condition of the sample. The resulting output is a system of statistical, commulant and Laplace methods, each systems produce a size distribution in the intensity, number and volume respectively.

Table 4 shows the measurement results of samples $\mathrm{C} 1, \mathrm{C} 2$ and $\mathrm{C} 3$ using the PSA. Mode analysis commulant produce a size distribution in number for the three samples, the results of this analysis showed that at the same speed the longer the milling time the particle size (particle diameter) produced smaller.

Table 4. The particle size of the sample $\mathrm{C} 1, \mathrm{C} 2$ and $\mathrm{C} 3$

\begin{tabular}{|c|c|c|c|}
\hline \multirow{2}{*}{$\begin{array}{c}\text { Sample } \\
\text { Code }\end{array}$} & \multicolumn{3}{|c|}{ Milling parameters and results } \\
\cline { 2 - 4 } & $\begin{array}{c}\text { Time } \\
\text { (minute) }\end{array}$ & Particle Size (nm) & $\begin{array}{c}\text { D mean } \\
\text { number }(\mathrm{nm})\end{array}$ \\
\hline C1 & 90 & $537.17-6,167.58$ & $2,162.66$ \\
\hline C2 & 180 & $74.15-1,412.91$ & 458.77 \\
\hline C3 & 270 & $64.58-1,122.80$ & 387.89 \\
\hline
\end{tabular}

The measuring process is done quickly. Calcium particles in solution are affected by gravity, so in a solution that is not stable enough, calcium particles are easy to form sedimentation. Sedimentation in the solution is very harmful because it would complicate measurements and eliminates the homogeneity of the solution. Brown motion of scattering particles (particles of calcium) led to fluctuations in the spread of the light, so that will produce a more volatile graph. Graph of the relationship between particles size with distribution number of samples C1, C2 and C3 are presented in Figure 7.

SEM-EDX analysis conducted to observe the microstructure and elemental composition of the sample C3. Figure 8 shows the morphology of microscopic samples $\mathrm{C} 3$ and EDX results. From the SEM photograph appears that the morphology of $\mathrm{Ca}(\mathrm{OH})_{2}$ (sample $\mathrm{C} 3$ ) as dots that connect to each other. The particles are mutually agglomerating the same as $\mathrm{CaO}$ samples (Figure 8). As shown in Figure 8(c) on the sample C3 contained some elements. Two elements that dominate are the elements $\mathrm{Ca}$ and $\mathrm{O}$. The other elements, namely $\mathrm{C}, \mathrm{Mg}, \mathrm{Al}$ and $\mathrm{Si}$ are very few in number as shown in Figure 8(c).

(a)




International Journal of Biomedical Engineering and Science (IJBES), Vol. 4, No. 1, January 2017

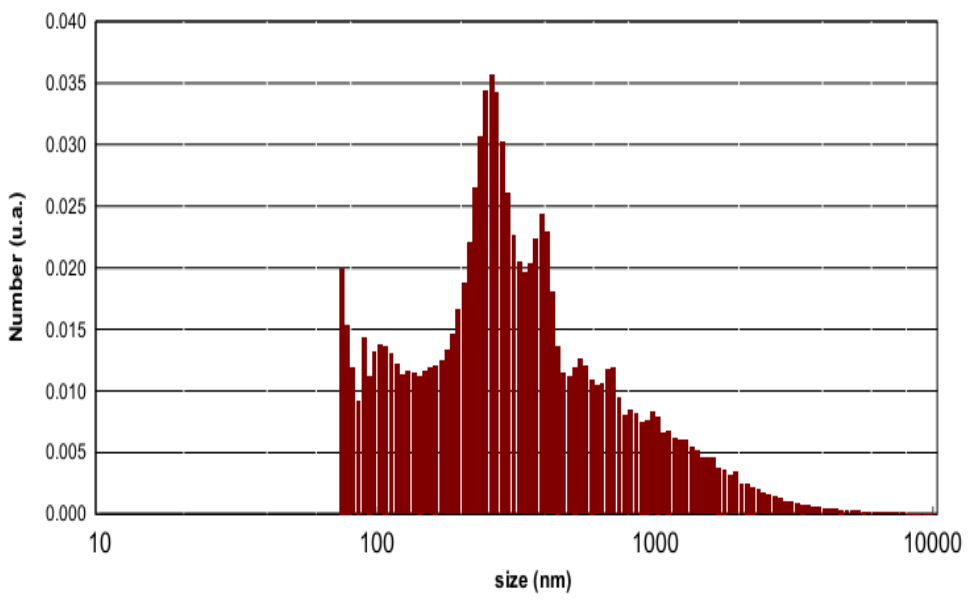

(b)

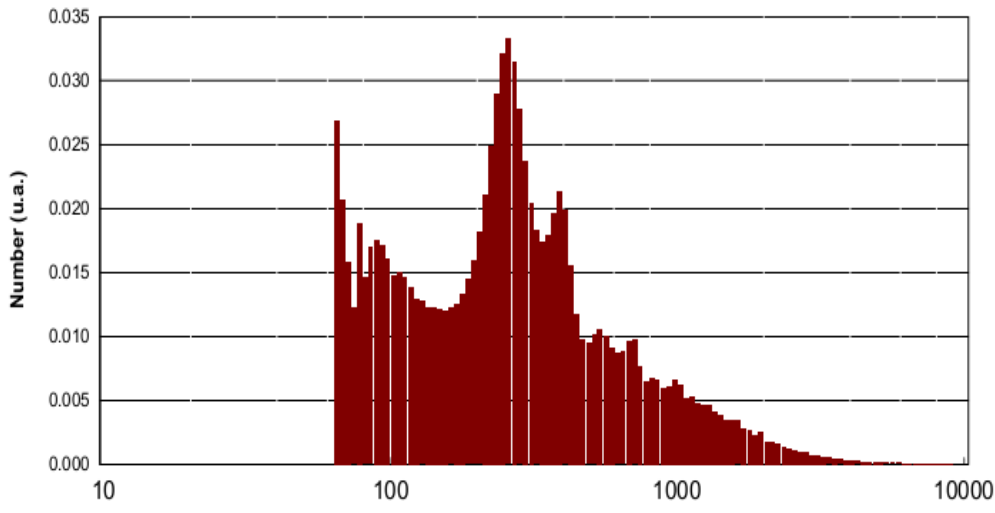

(c)

size (nm)

Figure 7. Graph of the relationship between particle size with distribution number of samples: (a) a sample $\mathrm{C}_{1}$ (b) samples $\mathrm{C}_{2}$ and (c) samples $\mathrm{C}_{3}$

SEM-EDX characterization aims to determine the form of the compounds and compositions contained therein. Based on the results of SEM-EDX hydroxyapatite in Figure 8, shows a uniform crystal by agglomeration of $10 \mu \mathrm{m}$ and a ratio of $\mathrm{Ca} / \mathrm{P}$ of 1.3 . Based on existing theory, the ratio $\mathrm{Ca} / \mathrm{P}$ of hydroxyapatite was $1.67^{22]}$.

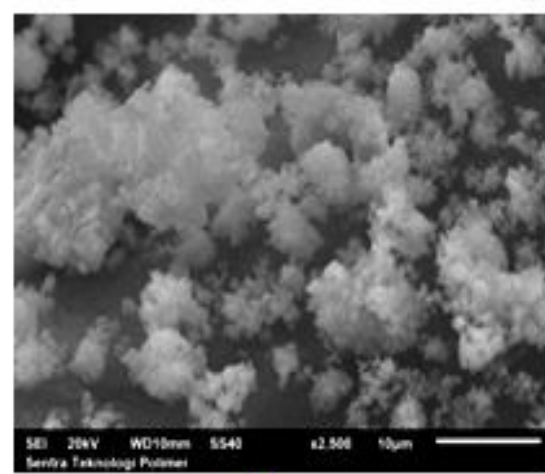

(a)

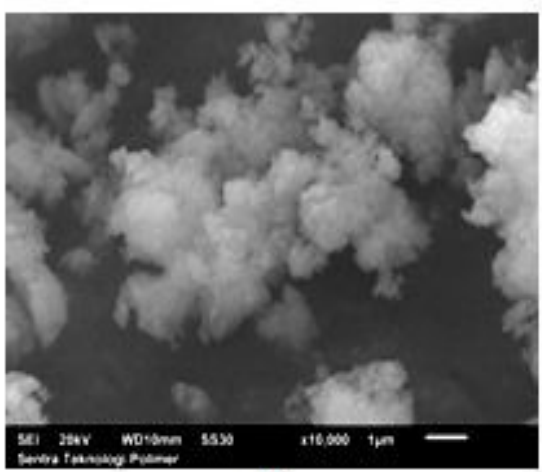

(b) 


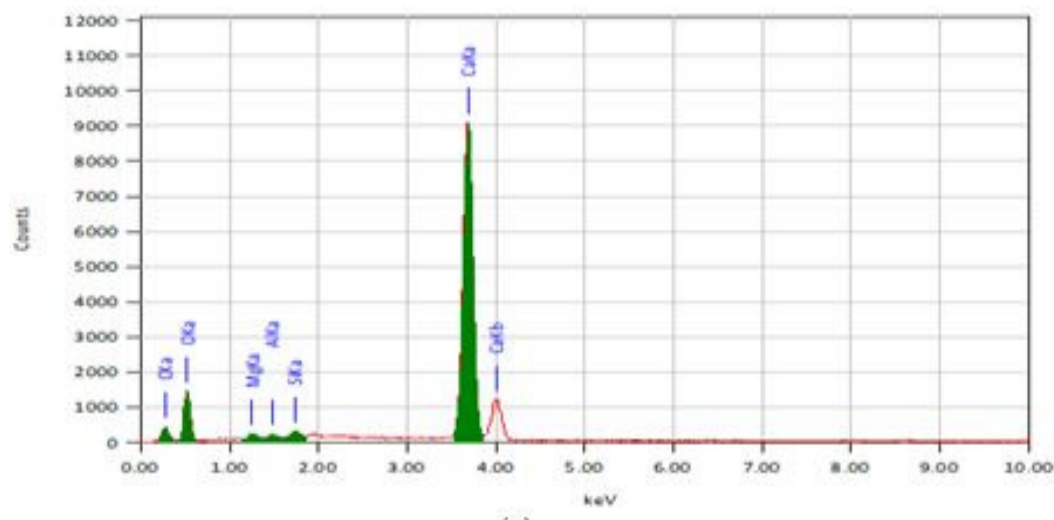

(c)

Figure 8. SEM micrograph of calcium hydroxide (sample $\mathrm{C}_{3}$ ) magnification: (a) $2.500 \mathrm{x}$ (b) $10.000 \mathrm{x}$ and (c) the data EDX

\section{CONCLUSION}

Hydroxyapatite nanoparticles successfully created through wet chemical precipitation method using calcium oxide derived from limestone and diammonium phosphate as a precursor. Powdered calcium oxide which is characterized by a particle size analyzer and it shows that the average size prior to milling is $45 \mu \mathrm{m}$ and after grinding varies between 387.89 to $2,126.66 \mathrm{~nm}$ for the duration of the grinding process. The longer the duration of grinding, the smaller size of the calcium precursor will be obtained. The nanocrystalline hydroxyapatite is characterized by scanning electron microscopy and transmission electron microscope EDX. Morphology of hydroxyapatite is agglomerate and needle-like shaped with a length of $10 \mathrm{~nm}$ to $150 \mathrm{~nm}$ and a diameter of about $10 \mathrm{~nm}$ to $40 \mathrm{~nm}$. The size of hydroxyapatite crystals can be influenced by the level of supplemental calcium solution, for the highest level has the smallest size of hydroxyapatite crystals.

\section{ACKOWLEDGEMENT}

The author would like to thank the Chairman of BPPT has financed its activities through DIPABPPT, as well as Director of Center for Materials Technology who has supported this program. Thanks also to colleagues who have jointly conduct this activity.

\section{REFERENCES}

1. Shubri, E. dan Armin, I. 2014. Penentuan Kualitas Batu Kapur dari Desa Halaban Kabupaten Lima Puluh Kota di Laboratorium Dinas Energi dan Sumber Daya Mineral Provinsi Sumatera Barat. Universitas Bung Hatta. Padang.

2. Pusat Penelitian dan Pengembangan Teknologi Mineral dan Batubara. 2005. Ulasan Batu Kapur/Gamping. http://www.tekmira.esdm.go.id/data/Batukapur/ulasan.asp?xdir=Batukapur\&commId=35\&comm $=$ Batu\%20kapur/gamping. Diakses tanggal 28 Februari 2014.

3. Carr D.D and Rooney L.F.F., "Limestone and Dolomit", Industrial Minerals, March 1990. 
International Journal of Biomedical Engineering and Science (IJBES), Vol. 4, No. 1, January 2017

4. Dahlan K., Sari Y.W., Soejoko DS., 2006, Karakterisasi Gugus Fosfat dan Karbonat dalam Tulang Tikus dengan Fourier Transform Infrared (FT-IR) Spectroscopy, J. Sains. Material Indonesia : 221-224.

5. Hin TS. 2004. Engineering Materials for Biomedical Application. Singapura (SG): World Scientific.

6. Karakas A, Hazar Y AB, Ceylan E D, Dogan M. 2012. Effect of different calcium precursors on biomimetic hydroxyapatite powder properties. International Congress on Avances in Applied Physics and Materials Science: 201; Istambul, Turki. Istambul (TR). Acta Physica Polonica A. 121(1): 236-239.

7. Wahl DA, Czernuszka JT. 2006. Collagen-hydroxyapatite composites for hard tissue repair. European Cells and Materials. 11: 43-56.

8. Aoki, H. 1991. Science and Medical Application of Hydroxyapatite. Tokyo (JP) : JAAS.

9. Rajkumar M, Meenakshi Sundaram N, Rajendran V. 2011. Preparation of size controlled, stoichiometric and biosesorbable hydroxyapatite nanorod by varying initial $\mathrm{pH}, \mathrm{Ca} / \mathrm{P}$ ratio and sintering temperatur. Digest Journal of Nanomaterials and Biostructures. 6(1): 169-179.

10. Herdianto N. 2011. Studi bioresorbabilitas biokeramik biphasic calcium phosphate (BPC) sebagai material pengganti tulang[tesis]. Salemba (ID): Universitas Indonesia.

11. Dahlan K. Prasetyani F. Sari YW. 2009. Sintesis Hidroksiapatit dari Cangkang Telur Menggunakan Dry Method. Jurnal Biofisika. 5(2): 71-78.

12. Nilsson M, Wang JS, Wielanek L, Tanner KE, Lidgren L, 2004. Biodegradation and biocompatability of a calcium sulphate-hydroxyapatite bone substitute. The Journal of Bone \& Joint Surgery (Br). January 2004; 86-B : 120-5

13. Sutherland D, Bostrom M, 2005. Grafts and Bone Graft Substitutes. Bone Regeneration and Repair, Biology and Clinical Applications. pp. 133

14. Follet H.; Boivin G.; Rumelhart C. et al. The degree of mineralization is a determinant of bone strength: a study on human calcanei. Bone 345: 783-9; 2004.Dahotre, 2008

15. Dahotre, N. B. and Paital, S. R., 2009, "Calcium Phosphate Coatings for Bioimplant Applications: Materials, Performance Factors and Methodologies", Journal of Materials Science and Engineering, 66, 1-70

16. V'azquez, Guzm'an C, Barba C, Pi'na, Mungu'ia N. (2005). Stoichiometric hydroxyapatite obtained by precipitation and sol gel processes. Revista Mexiana De F'isica 51(3): 284-239.

17. Lane NE. (2001). Osteoporosis, Rapuh Tulang : Petunjuk untuk Penderita dan Langkah-langkah Pengamanan untuk Keluarga. Raja grafindo Persada, Jakarta.

18. Rivera-Munoz, EM., (2011). Hydroxyapatite-based Materials: Synthesis and Characterization, Biomedical Engineering-frontiers and Challenges,. Spinger. ISBN: 978-953-307-309-5.

19. Park JB. (1984). Biomaterials Science and Engineering. USA: Plenum Press.

20. Amri A, Amrina, Saputra E, Utama PS, Kurniati A. 2007. Pengaruh suhu dan ukuran butir terhadap kalsinasi batu gamping kab. Agam pada proses pembutan kapur tohor. J Sains dan Teknologi. 6(1): 10-13.

21. Suparno. 2012. Dinamika Partikel Koloid. Yogyakarta (ID): UNY Press.

22. Suryadi, 2011, Sintesis dan Karakterisasi Biomaterial Hidroksiapatit dengan Proses Pengendapan Basah, Engineering Faculty, University of Indonesia, Depok, Indonesia. http:/kampungminers.blogspot.co.id/2012/09/batu-gamping.html 